\title{
Surface subsidence associated with abandoned mine workings in the Goldenville mining district, Nova Scotia
}

\author{
J.D. Hill ${ }^{1}$ L.A. Maddison ${ }^{1}$ and C. Kavanaugh ${ }^{2}$ \\ 'Department of Mining and Metallurgical Engineering, Technical University of Nova Scotia, \\ P.O. Box 1000, Halifax, Nova Scotia B3J 2X4, Canada \\ ${ }^{2}$ Nova Scotia Department of Natural Resources, P.O. Box 698, Halifax, Nova Scotia B3J 2T9, Canada
}

Date Received March 14, 1997

Date Accepted May 23, 1997

\begin{abstract}
Mining in Meguma gold districts has resulted in the development of hundreds and possibly thousands of underground stopes since gold was first discovered in 1861. These stopes are on the order of 1 to $2 \mathrm{~m}$ wide and extend up to hundreds of metres along strike and tens of metres in height. Many are open or partially filled and capped by surface crown pillars of quartz and phyllite that are as little as $2 \mathrm{~m}$ thick vertically. The majority of these stopes have been abandoned for more than fifty years and the long term stability of their surface crown pillars is uncertain.

Rock mass behaviour and surface subsidence have been monitored in part of the Goldenville mining district since 1991. Surface subsidence basins have increased in both number and depth during this period. Stope locations and the nature of crown pillars above the stopes are poorly defined due to lack of accurate mining records and the presence of overburden. Furthermore, some of the subsidence features in the area are obviously related to the failure of overburden plugs rather than bedrock caps. For these reasons, a causal relationship between surface crown pillar failure and the surface subsidence features currently existing in the Goldenville district cannot be established at this time. However, time domain reflectometry and structural data suggest that the near-surface rock mass between and above abandoned stopes is undergoing progressive degradation by gravity-induced failure of slab-like blocks along intersecting and closely-spaced bedding, cleavage and joint surfaces. Uncertainties in factors such as rock mass quality, crown pillar dimensions and water table fluctuations make it impossible to predict when and where crown pillars might fail. However, failure of the weaker crown pillars and consequent surface subsidence are inevitable if these rock mass movements continue indefinitely.
\end{abstract}

L'extraction minière dans les districts aurifères de Meguma a provoqué l'établissement de centaines, et possiblement de milliers, de chambres souterraines depuis qu'on y a découvert de l'or pour la première fois en 1861. Ces chambres ont d'un à deux mètres de largeur et des dizaines de mètres de hauteur, et elles longent des filons sur des centaines de mètres. Beaucoup sont ouvertes ou partiellement remplies et coiffées de stots de surface de quartz et de phyllite pouvant n'avoir que deux mètres d'épaisseur verticalement. La majorité de ces chambres sont abandonnées depuis plus de 50 ans et la stabilité à long terme de leurs stots de surface est incertaine.

On surveille le comportement des masses rocheuses et l'affaissement de surface dans une partie du district minier de Goldenville depuis 1991. Le nombre et la profondeur des bassins d'affaissement de surface se sont accrus au cours de cette période. Il est difficile de définir les emplacements des chambres et la nature des stots audessus des chambres en raison de l'absence de registres miniers précis et de la présence de morts-terrains. De plus, certaines des caractéristiques de l'affaissement dans le secteur sont nettement liées à la défaillance de l'obturation à l'aide de morts-terrains plutôt que des chapeaux de substrat rocheux. C'est pourquoi on ne peut pas établir pour le moment une relation de cause à effet entre la défaillance des stots de surface et les caractéristiques de l'affaissement de surface existant présentement dans le district de Goldenville. La réflectométrie à dimension temporelle et les données structurales permettent toutefois de supposer que la masse rocheuse en sub-surface entre les chambres abandonnées et au-dessus de celles-ci est en train de subir une dégradation progressive en raison de la défaillance gravitaire des blocs en tranches longeant l'intersection et les surfaces rapprochées des fissures, du clivage et de la stratification. Les incertitudes par rapport aux facteurs, comme la qualité des masses rocheuses, les dimensions des stots de surface et les fluctuations du niveau phréatique, empêchent les géologues de prédire quand et où peuvent s'écrouler les stots. Il est cependant inévitable que les stots plus faibles cèdent et que se produise l'affaissement de surface consécutif si ces masses rocheuses continuent à bouger indéfiniment.

[Traduit par la rédaction]

\section{INTRODUCTION}

Land subsidence ranges from a general lowering of the surface forming circular to elongate basins, to the formation of steep-sided pits with appreciable depths. Tension cracks and/or compression ridges may accompany these features. These ground movements can cause damage to built structures, modification of surface and ground water drainage systems, and even loss of life. Surface subsidence due to underground mining is a long-standing problem in Nova 
Scotia, especially in coal producing areas (e.g., Gillis, 1992; Forrester et al., 1995). Subsidence has also been reported in the Meguma Zone where it is related to extensive underground workings associated with abandoned gold mines (e.g., Province of Nova Scotia, 1911; Stephens, 1974).

The Department of Mining and Metallurgical Engineering at the Technical University of Nova Scotia, in conjunction with Canmet Mining Research Laboratories in Ottawa, has been studying the stability of surface crown pillars at Goldenville since 1991 (Fig. 1). This project included surface surveying and bedrock mapping, diamond core drilling for geotechnical studies, and monitoring of rock mass behaviour using time domain reflectometry (Hill, 1993; Aston et al., 1994). Although surface subsidence features existed prior to this project, and indeed were one of the criteria used to select the project location, these features have increased in number and magnitude since 1991. This paper documents the history and current extent of surface subsidence at Goldenville, and relates the surface subsidence to previous mining activities and crown pillar degradation.

\section{Geology}

The Goldenville mining district lies within the Meguma Zone, a $33,000 \mathrm{~km}^{2}$ belt of rocks underlying the southern half of Nova Scotia (e.g., Schenk, 1978; Williams and Hatcher, 1982; Waldron, 1987). The Meguma Zone consists predominantly of metasedimentary rocks of the Cambro-Ordovician Meguma Group, intruded by granitoid plutons of late Devonian age. The Meguma Group is divided into two apparently conformable units - the psammitic Goldenville For- mation and the younger pelitic Halifax Formation. These rocks have been metamorphosed from lower greenschist to middle amphibolite facies conditions and folded into a series of east- to northeast-trending synclines and anticlines.

The crown pillar monitoring site at Goldenville is situated on the southern limb of a major anticline in the Goldenville Formation, in and around a chain link fence erected in 1988 to prevent public access to an area of obvious surface subsidence (Fig. 2). The anticline plunges 15 to $30^{\circ} \mathrm{W}$ and its axial surface dips about $70^{\circ} \mathrm{N}$ (Faribault, 1898). Away from the hinge line, strata on the north limb dip about $45^{\circ} \mathrm{NE}$ whereas strata on the south limb dip 70 to $90^{\circ}$ both north and south. The dominant lithology is massive to faintly laminated metawacke that forms beds 0.3 to several metres in thickness. Spaced cleavage is well developed and dips 65 to $85^{\circ} \mathrm{N}$, even where beds dip to the south. Grey to black phyllite makes up 10 to $20 \%$ of the sequence. Phyllite beds vary from 1 to $30 \mathrm{~cm}$ thick, although a $3 \mathrm{~m}$ thick bed of graphitic phyllite was observed in one outcrop in the surrounding area. Cleavage is oriented parallel to bedding and imparts a strong fissility to the phyllite. Both the spaced and phyllitic cleavages are more or less axial planar to the major anticline.

Several cross-faults, with as much as $13 \mathrm{~m}$ of horizontal displacement, were recognized in the area by Faribault (1898). Fault spacing appears to be on the order of tens to hundreds of metres. Hedley (1941) noted that there is a tendency for weak ground to lie immediately above and below faults in the underground workings. However, it is not known if any faults occur within the subsidence monitoring area. Four joints sets have been identified, with average orientations of $005^{\circ} / 80^{\circ} \mathrm{E}, 325^{\circ} / 80^{\circ} \mathrm{NE}, 035^{\circ} / 90^{\circ}$ and subhorizontal

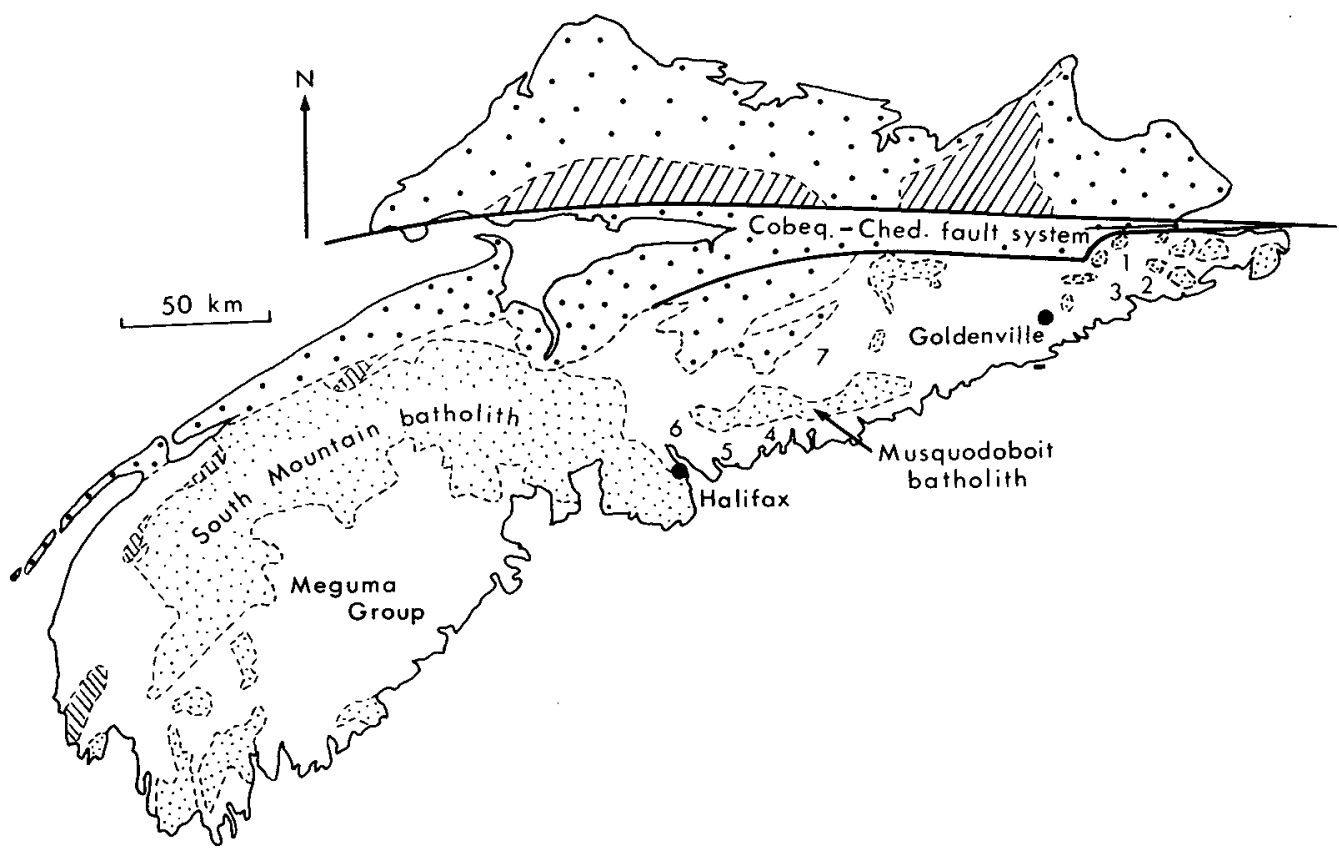

Fig. 1. Mainland Nova Scotia showing the Meguma Zone to the south of the Cobequid-Chedabucto fault system and the Avalon Zone to the north. Meguma Zone includes the Meguma group (unmarked), Silurian supracrustal rocks (ruled) and Devonian granite (fine dots). Avalon Zone includes metamorphic basement rocks (ruled) and Carboniferous and younger cover rocks (coarse dots). The Goldenville crown pillar monitoring site is indicated. Numbered sites mentioned in text are Forest Hill (1), Goldboro and Wine Harbour (2), Country Harbour (3), Lake Catcha (4), Montague (5), Waverley (6) and Moose River (7). 


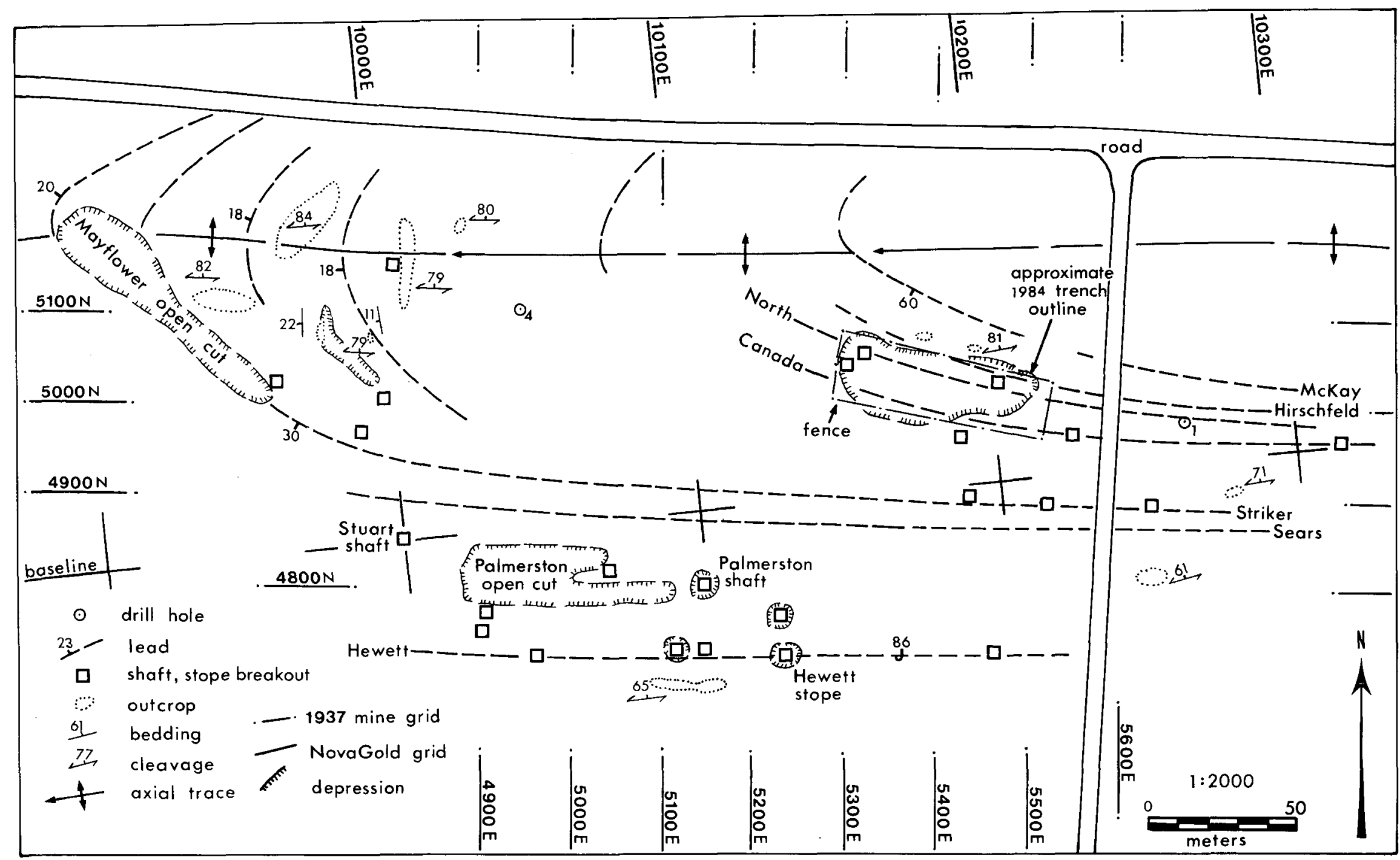

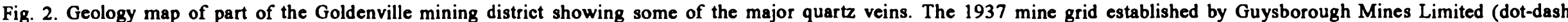

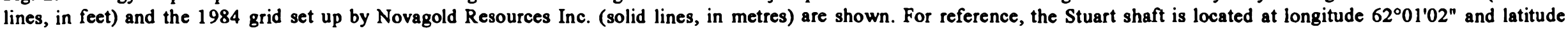
$45^{\circ} 07^{\prime} 22^{\prime \prime}$ in N.T.S. map sheet $11 \mathrm{E} / 1 \mathrm{~A}$. 
(Hill, 1993). Of these, the north-trending set is dominant, and has a spacing of $5 \mathrm{~cm}$ to $3 \mathrm{~m}$. Joints in the remaining sets are relatively uncommon, with spacings of $0.5 \mathrm{~m}$ to more than $10 \mathrm{~m}$. Most joints are closed to slightly open with unfilled apertures of up to $1 \mathrm{~mm}$. Joint surfaces are generally unweathered and fairly smooth.

Quartz veins include both bedding-parallel leads and minor cross-cutting "angulars" (Hedley, 1941). Nearly all mining was restricted to the bedding-parallel leads, and the following description applies to these leads only. The bedding-parallel leads comprise a series of closely-spaced veins, many of which wrap around the anticlinal closure forming "saddles" (Malcolm, 1929). More than 100 leads have been worked in the Goldenville district, yielding grades up to $100 \mathrm{oz} / \mathrm{t}$. Gold is concentrated in payshoots lying within the veins, and on the south side of the anticline these payshoots have been worked over a total strike length of $1350 \mathrm{~m}$ (Malcolm, 1929). Typical payshoots were mined for lengths of 6 to 18 $\mathrm{m}$ (Faribault, 1899). Most veins range from 7 to $35 \mathrm{~cm}$ in thickness on the anticlinal limbs and up to $3 \mathrm{~m}$ in thickness at the closure (Hedley, 1941), and are spaced at intervals of a few metres on average. Although most stopes followed individual leads, closely spaced vein packages were often mined as "belts" that were 1 to $4 \mathrm{~m}$ in width (Stewart, 1903; Brunton, 1927).

Within the fenced area, Faribault (1898) named three major veins as the North, Seven Foot and Canada leads, running north to south (Fig. 3). Mine maps from the early 1900s indicate the same sequence to be Hirschfeld (also spelled Hirschfield), North and Canada. While attempting to excavate a bulk sample in 1984, Northumberland Mines Limited uncovered six major veins in the same area but was unable to relate the sequence to that identified by Faribault (Coates and Freckelton, 1989). Diamond drilling during the current project detected eight quartz veins beneath the fenced area, with thicknesses ranging from 0.1 to $2.5 \mathrm{~m}$. Three of these eight veins have been tentatively identified as the Hirschfeld, North and Canada based on their surface positions. The geology in the eastern part of the fenced area is depicted in Figure 4. Five leads and/or stopes were detected by drilling. The North lead appears to be plugged by overburden at that location, whereas an unnamed lead immediately to the south is interpreted to have a thin surface crown pillar of quartz.

\section{Mining histoRY}

Mining began in the Goldenville district in 1861 when gold was first discovered by Nelson Nickerson of Sherbrooke, and continued until 1942 when the last mine ceased operation because of manpower and supply shortages caused by World War II. Goldenville was the most productive of all of the Meguma gold mining districts, with peak production of 9463 ounces occurring in 1867 (Malcolm, 1929). Mining companies neglected to preserve mine records and plans in the early decades, and apart from the district survey by Faribault (1898), very little detailed information is available concerning the underground workings and mining methods (Brunton, 1927; Malcolm, 1929). The information presented below has been gleaned from a few key publications as well as a review of the assessment reports and maps on file in the library of the Nova Scotia Department of Natural Resources. The old Liscomb Road and the Stuart shaft, which appear on many of the old mine plans and geology maps, serve as reference points (see Fig. 2).

By the summer of 1862 , shafts and trenches were everywhere, ranging up to $20 \mathrm{~m}$ in depth (Kuusisto, 1988). For the first two decades of mining activity, numerous small companies worked mine leases that ran as little as $6 \mathrm{~m}$ along the strike of the vein (Evans, 1938). Shallow open cuts were used initially wherever quartz veins, and especially veins with visible gold, were exposed at the surface or after removal of the overburden. Deeper access was provided by multiple shafts sunk at intervals of 15 to $30 \mathrm{~m}$ along a vein to depths of 10 to $50 \mathrm{~m}$. Levels were driven at the bottoms to connect adjacent shafts, and veins were worked either by overhand or underhand stoping using wood stagings or broken rock as working platforms. Where overhand stoping was used, abandoned stopes were probably left at least partially filled with hand sorted waste rock. With underhand stoping, all of the ore had to be removed, and many stopes appear to have been left open, with occasional stulls, cribs and rock pillars used for support. The miners followed single veins using hand drilling and black powder, taking as little waste rock as possible (Brunton, 1927). For example, the Palmerston Company worked the Palmerston lead (Fig. 2) to within 4 $\mathrm{m}$ of the surface using two shafts lying $30 \mathrm{~m}$ apart and 27 to $36 \mathrm{~m}$ in depth (Brunton, 1927). The New York and Sherbrooke Company worked the Harrison lead $43 \mathrm{~m}$ along strike to within $5 \mathrm{~m}$ of the surface north of the anticlinal axis. The Palmerston Company sunk three 15 to $20 \mathrm{~m}$ deep shafts on the Sears lead and stoped to surface along a strike length of $18 \mathrm{~m}$ (Fig. 2). A longitudinal mine section in the assessment files of the Nova Scotia Department of Natural Resources library depicts a near-surface stope on the Hewett lead that is $65 \mathrm{~m}$ long and up to $27 \mathrm{~m}$ high, with a surface crown pillar of 2.5 to $5 \mathrm{~m}$ thick lying between four leadparallel shafts (Fig. 5).

By 1872, some of the smaller leases had been consolidated and deeper shafts such as the $150 \mathrm{~m}$ Wellington were developed (Kuusisto, 1988). Between 1872 and 1893 when mine profits declined, many mine owners leased their properties to tributers. As each tributer worked with minimum capital on short term leases, little care was given to the long term life of the operation. Shafts were left uncovered, inadequate timbering was used underground, few records were maintained and open stopes and trenches were left to fill with rubble and water. In some cases, the surface crown pillars of veins were removed, destroying the roofs of the mines. By 1899, leads on the south side of the anticline had been worked to depths of up to $213 \mathrm{~m}$ (Faribault, 1899). Since that time, some of these open workings have been backfilled to surface while others have been plugged at the top with large boulders or wood stagings and covered with overburden. 


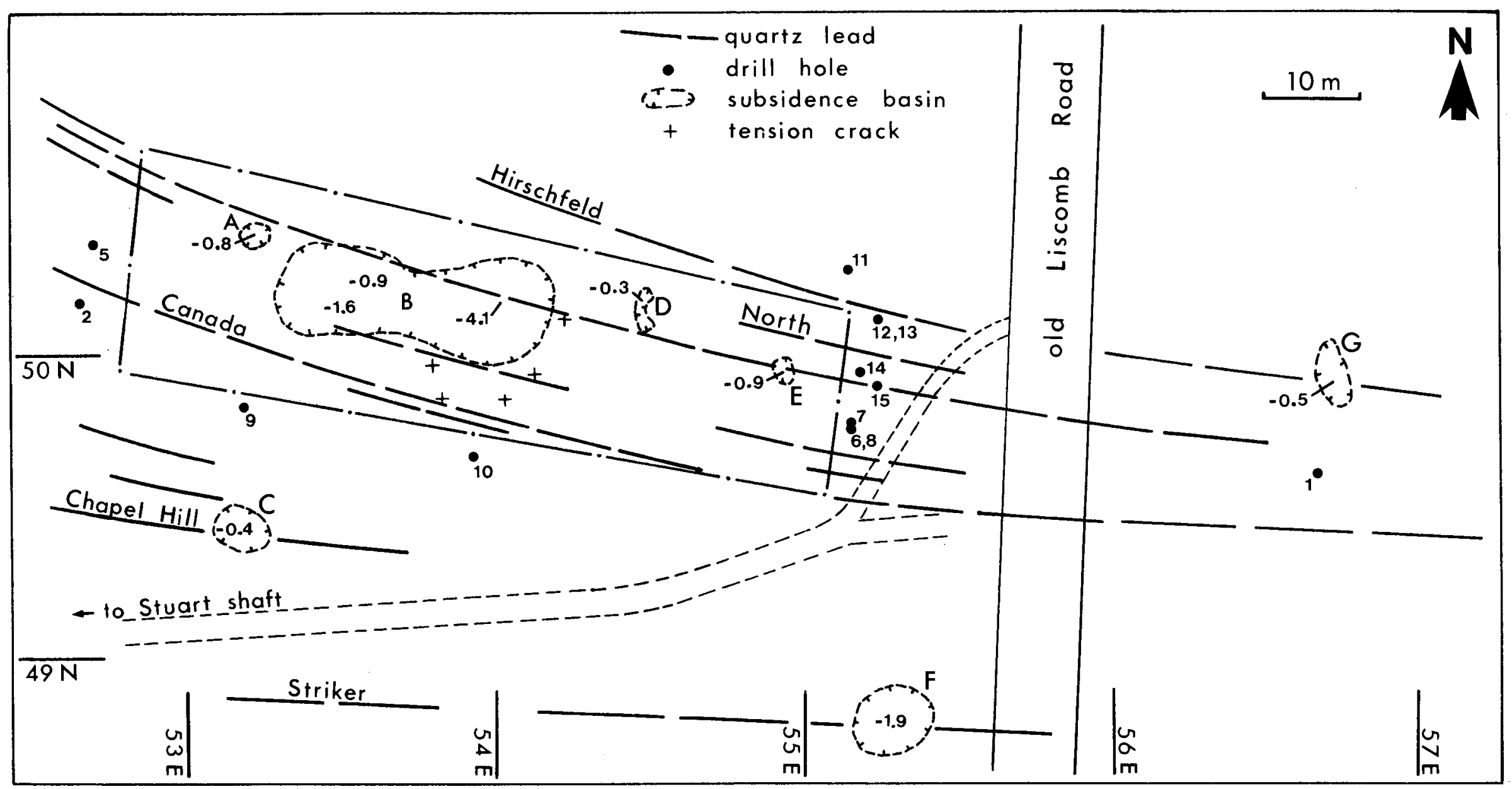

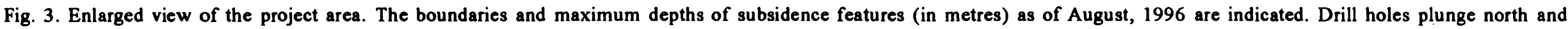
south at 35 to $50^{\circ}$. Individual subsidence basins are labelled (A to $G$ ). The locations and names of specific leads are uncertain. 


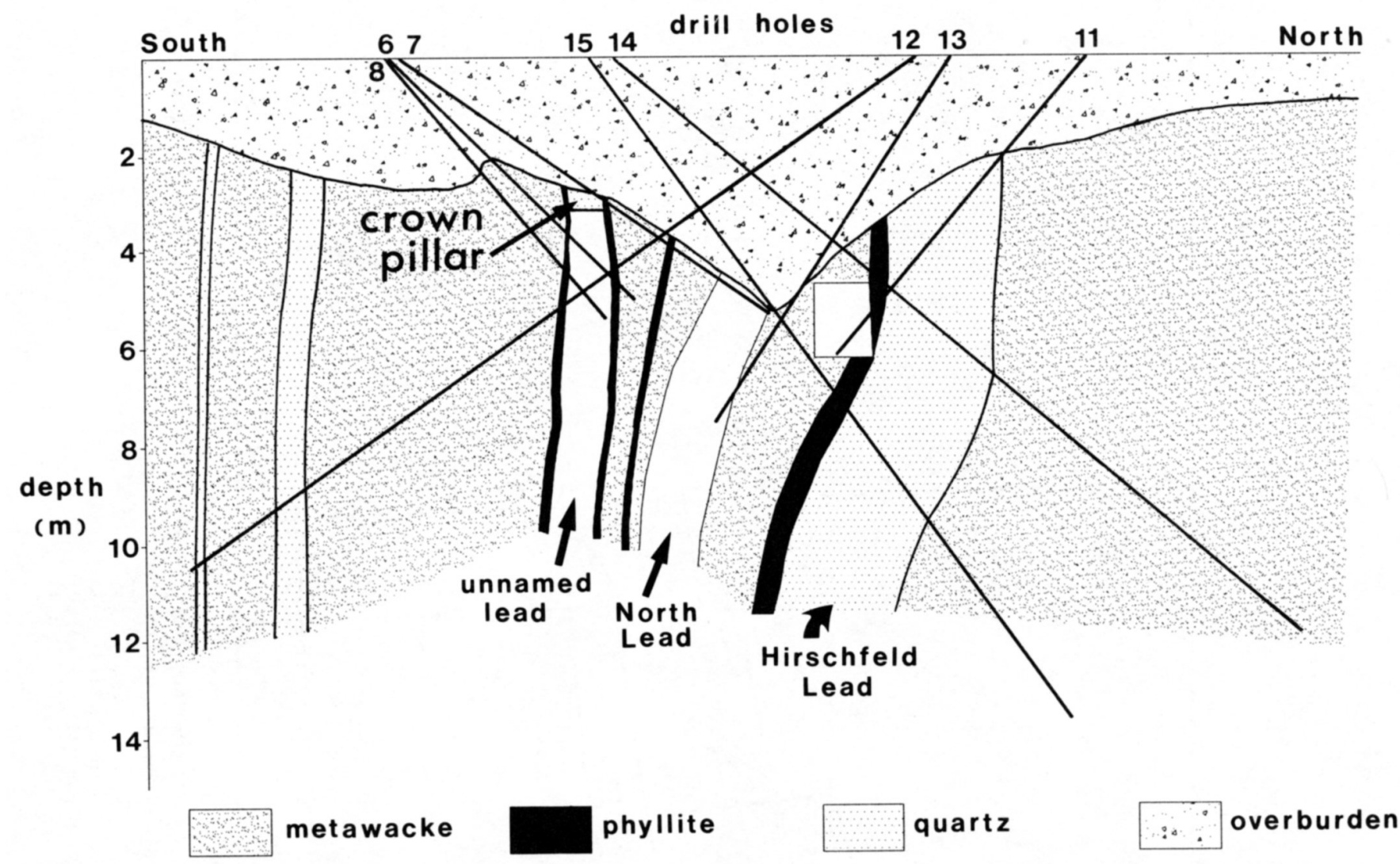

Fig. 4. Cross-section inferred from drill hole logs at the east end of the fenced area. The North lead (capped by overburden) and an unnamed lead immediately to the south (capped by thin surface crown pillar) have been mined out near the surface. The rectangle intersected by drill hole \#11 appears to be a mining drift.

Toward the end of the 1800 s, more experienced and wellfinanced owners began to establish larger companies using better mining and milling practices. This change coincided with the gradual introduction of air-driven drills, dynamite, powered hoists with large skips and cyanide processing (Stewart, 1903; Evans, 1938). Production grades reported for the district gradually decreased due to greater efficiencies in mining, the cessation of hand cobbing of ore and different milling practices. For example, where large tonnages gave grades of 6 to $44 \mathrm{~g} / \mathrm{t}$ in 1871, average grade dropped to $4 \mathrm{~g} / \mathrm{t}$ by 1927 (Malcolm, 1929). Extensive operations centered on single shafts sunk to depths of 100 to $200 \mathrm{~m}$. One of these, the Stuart shaft (see Fig. 6), was begun in 1903 and became the center of operations for a series of different companies including the Nova Scotia and Mexican Company, the Goldenville Mining Company, Sherbrooke Mines and Power Company and Guysborough (also spelled Guysboro) Mines Limited (Brunton, 1927; Malcolm, 1929). By the time Guysborough Mines closed permanently in 1942, mining had reached the $183 \mathrm{~m}$ (600 foot) level and the underground workings extended for more than $475 \mathrm{~m}$ along strike and $200 \mathrm{~m}$ across strike. Figure 5 shows typical workings on the $49 \mathrm{~m}$ and $79 \mathrm{~m}$ (160 and 260 foot) levels on the Hewett lead. Veins lying within the fenced area such as the Canada lead were mined from the $49 \mathrm{~m}$ level as early as 1910 (Malcolm, 1929) and the North and Hirschfeld veins were worked on the $122 \mathrm{~m}$ (400 foot) and $183 \mathrm{~m}$ (600 foot) levels by 1940 (Messervey, 1940). Only minor stoping was done on the 152 $\mathrm{m}$ and $183 \mathrm{~m}$ (500 and $600 \mathrm{foot}$ ) levels prior to closure, since the Stuart shaft was only extended to $183 \mathrm{~m}$ in depth in 1938 (Province of Nova Scotia, 1939). However, despite the change to centralized mining operations in the 1900s, there were 262 separate shafts in the Goldenville district by 1933 , having an average depth of just $28 \mathrm{~m}$.

Shrinkage stoping was the dominant mining method used in the Goldenville district by the 1930s, although other methods, such as resuing, which was common elsewhere in the Meguma Zone, may have been used as well. Shrinkage stopes were developed by drifting within or beside the vein and then driving access raises to outline a block of ore that was typically 3 to $4 \mathrm{~m}$ in height. The ore was mined in successive overhand lifts of about $2 \mathrm{~m}$ each with broken ore used as the working platform. Sill pillars were left beneath overlying stopes, although these may have been recovered at later dates. Casual pillars were probably left where grade was lean or the hangingwall was weak (Province of Nova Scotia, 1939). Individual stopes were up to $190 \mathrm{~m}$ long and 25 to $36 \mathrm{~m}$ high, with crown pillars 8 to $20 \mathrm{~m}$ thick. Backfilling did not become standard practice until the 1930s when mining went deeper and became more mechanized. For example, J.P. Messervey in a letter to the Inspector of Mines in 1936, reported that backfilling was planned for an open stope be- 


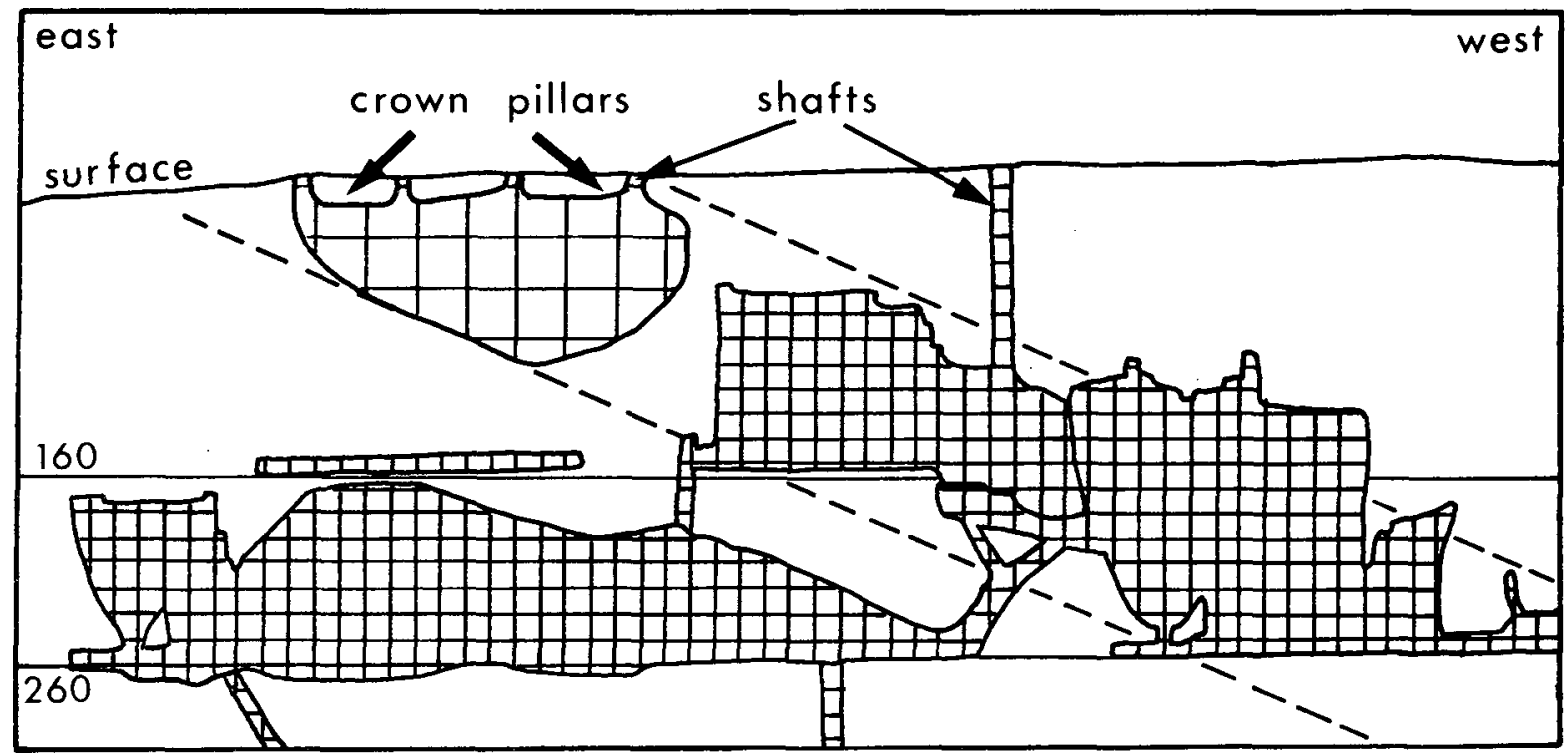

Fig. 5. Longitudinal section of mine workings on the Hewett lead as of August, 1937, taken from the assessment files of the library of the Nova Scotia Department of Natural Resources. Older, near-surface workings were accessed by multiple short shafts in the vein. More recent workings were accessed from the 49 and $79 \mathrm{~m}$ (160 and 260 foot) levels of the Stuart shaft. Dashed lines indicate the rake of an oreshoot within the vein.

tween the $49 \mathrm{~m}$ and $79 \mathrm{~m} \mathrm{(160} \mathrm{and} 260$ foot) levels on the Striker lead. It is unknown if that backfilling was ever completed, although it was reported the next year that backfilling of stopes in general was proceeding at a rapid rate (Messervey, 1937). At that time, some of the older open stopes at higher levels were backfilled for safety reasons.

No mining occurred in the Goldenville area after 1942, until a $3500 \mathrm{t}$ bulk sample was taken by Goldenville Explorations Limited in 1984 (location of bulk sample shown in Fig. 2). Goldenville Explorations excavated a trench $48 \mathrm{~m}$ long, $12 \mathrm{~m}$ wide and 1.5 to $3 \mathrm{~m}$ deep to expose six beddingparallel veins between and including the North and Canada leads (Fig. 3). These leads were up to $1 \mathrm{~m}$ wide and had an average spacing across strike of about $2 \mathrm{~m}$. During removal of the vein quartz, they discovered that two sections of interbedded quartz, phyllite and metawacke were actually 1.5 to $3 \mathrm{~m}$ thick crown pillars that capped two open stopes. Each stope was 0.9 to $1.5 \mathrm{~m}$ wide and ran continuously along the length of the trench (P. Smith, personal communication, 1994). The depths of the open stopes along the leads were not determined because they were filled with dark water. After removal of the crown pillars, the tops of the stopes were plugged with large boulders and the whole area was covered with overburden, including a filled shaft that was uncovered during excavation.

In 1988, MPH Consulting Limited dewatered and rehabilitated the Stuart shaft and underground workings of Guysborough Mines Limited on behalf of NovaGold Resources Incorporated (Coates and Freckelton, 1989). Two raises to surface were re-established, one using the old Palmerston shaft and the other using an unnamed shaft on the Canada lead, $50 \mathrm{~m}$ east of drill hole \#1 (see Fig. 2). Both raises are connected to the Stuart shaft on the 160 foot level. During dewatering of the Guysborough Mines workings, surface subsidence developed in three places previously capped by surface materials: (1) around the old Palmerston shaft, (2) above part of an old stope on the Hewett lead which broke through to surface, (3) and in the area of the 1984 bulk sample. When the exploration program ended in 1988, a $2 \mathrm{~m}$ high chain link fence was erected around each area of subsidence. The largest fenced area, shown in Figure 3, surrounds the area of the 1984 bulk sample.

\section{SURFACE SUBSIDENCE FEATURES}

At the beginning of this study in 1991, horizontal locations in and around the fenced area were determined by theodolite and electronic distance measuring equipment, and the depths of subsidence features were measured by triangulation with rod and compass. Precise three-dimensional coordinates of surface features, shown in Figure 3, were surveyed in August, 1996 using a Wild TC-1000 total station instrument. The center of the concrete platform capping the Stuart shaft was used to establish a base station in both surveys (Fig. 2).

The terrain within and south of the fence is relatively flat with a total relief of about $2 \mathrm{~m}$ (excluding subsidence basins). The ground rises 3 to $4 \mathrm{~m}$ east of the old Liscomb Road and more than $10 \mathrm{~m}$ just north of the fenced area in Figure 3. Surface drainage is absent excet for a small ephemeral brook a few metres south of the Striker lead that drains westward. The area is covered by bouldery till and coarse mine waste rock, except for a few small outcrops of bedrock (shown in Fig. 2). Diamond drilling indicates that the overburden ranges from 1 to $8 \mathrm{~m}$ thick. The water table, measured in open drill holes, varies from 1 to at least $6 \mathrm{~m}$ below surface between spring and fall. 


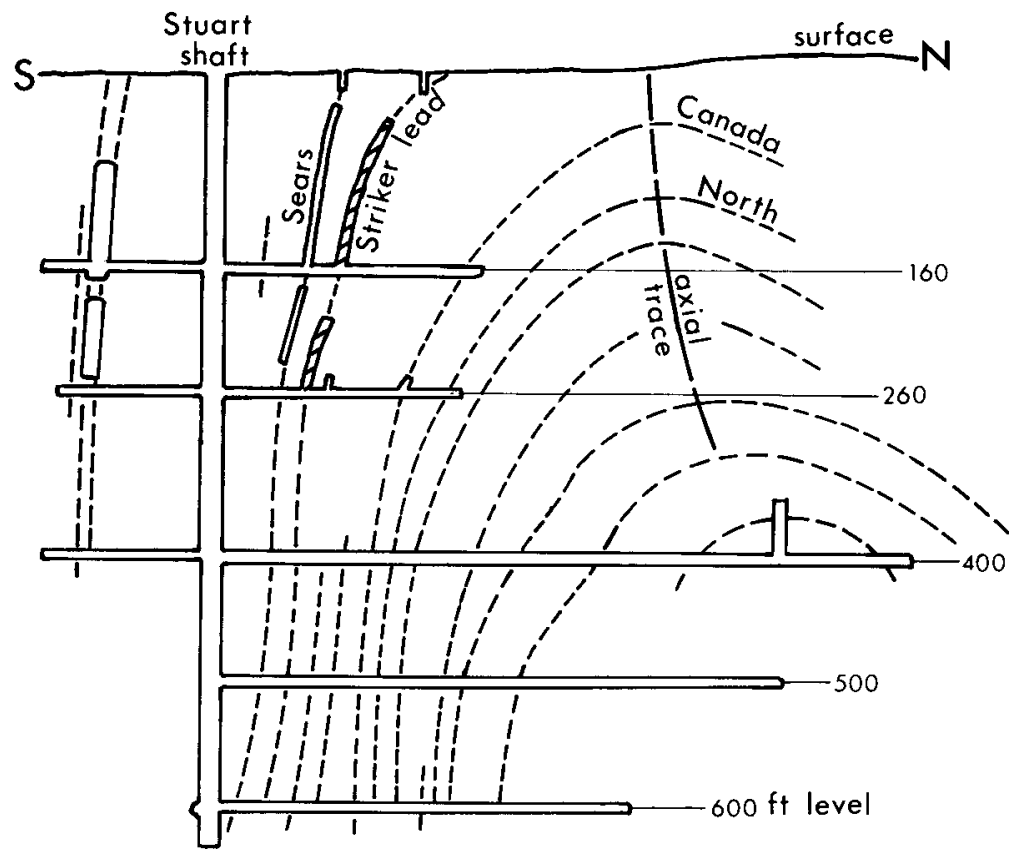

Fig. 6. Cross-section of underground workings of Guysborough Mines Limited (approximately 1940). Bedding-parallel leads are shown as dashed lines. Adapted from an unlabelled cross-section in the assessment files of the Nova Scotia Department of Natural Resources.

Seven separate subsidence basins have been measured (labelled A to $\mathrm{G}$ in Fig. 3). They range in current size from small depressions 1 to $3 \mathrm{~m}$ across and less than $1 \mathrm{~m}$ deep to a large irregular basin inside the fence (subsidence basin B) that is $27 \mathrm{~m}$ long and which includes a circular pit at its eastern end which is $4.1 \mathrm{~m}$ deep and $10 \mathrm{~m}$ wide: A series of linear to crescent-shaped tension cracks lie along the eastern and southern portions of the rim of this pit. Additional subsidence features exist outside the monitoring area in the Goldenville district. For example, a surface cave-in $300 \mathrm{~m}$ east of drill hole \#1 has revealed a $1.2 \mathrm{~m}$ wide open stope supported by occasional wood stulls. A shallow trench-like depression extends along the surface in the direction of the assumed lead. It was impossible to determine whether this depression is related to surface crown pillar failure or to gradual decay of a timber staging covered by overburden.

In 1991, when the monitoring project first started, no subsidence was observed outside the fence in the area shown in Figure 2 except for a very small subsidence feature just north of drill hole \#1 (subsidence basin G) along the apparent surface position of the Hirschfeld lead. At that time, the subsidence features inside the fence were well developed, but somewhat smaller than they are today. For example, the largest pit (east end of subsidence basin B), described in the preceding paragraph, was only about $9.1 \mathrm{~m}$ wide and $3.2 \mathrm{~m}$ deep in the summer of 1991. Subsidence basin C, which appears to lie above the Chapel Hill lead, first appeared in the spring of 1992. The steep-sided circular pit south of drill hole \#6 (subsidence basin F) developed in late 1995 or early 1996 and coincides with the position of an old shaft on the Striker lead.

\section{ROCK MASS CHARACTERISTICS AND BEHAVIOUR}

The near-surface rock mass in the vicinity of the fenced area is characterized by three different types of discontinuities: bedding, cleavage and joints. Although faults are also present, they are widely spaced and have little bearing on the following discussion. Based on both outcrop and drill core observations, bedding, cleavage and joint surfaces intersect to define tabular to wedge-shaped blocks (see Fig. 7) with aspect ratios of approximately 1:10:20. This inferred shape is supported by Messervey (1936) in his description of hangingwall failures on the Sears lead. Based on discontinuity spacing, the lengths of the blocks are probably in the range of a few centimetres to 1 to $2 \mathrm{~m}$ and are oriented more or less parallel to bedding and cleavage. From $79 \mathrm{~m}$ of core recovered from 14 geotechnical drill holes, average Rock Quality Designation (RQD) values (Deere, 1964) were found to be $42 \%$ for metawacke, $15 \%$ for quartz and $0 \%$ for phyllite. However, these RQD values should be used with caution as the core is only $47 \mathrm{~mm}$ in diameter and was taken using single barrel drilling equipment. The rock mass ranges from poor to fair in rock quality using the CSIR Geomechanics Classification for jointed rock masses devised by Bieniawski (1976).

Rock mass movements in the Goldenville district have been noted in the past when mining activities were ongoing. For example, Brunton (1927) described the necessity of using solid hardwood cribs to support the hangingwall of the Dewar lead where it dips $45^{\circ} \mathrm{NE}$ on the north side of the anticlinal axis. Messervey $(1936,1937)$ noted that slabs of rock tended to fall from the footwall of the Hirschfeld lead and the hangingwall of the Sears lead. Furthermore, dewa- 


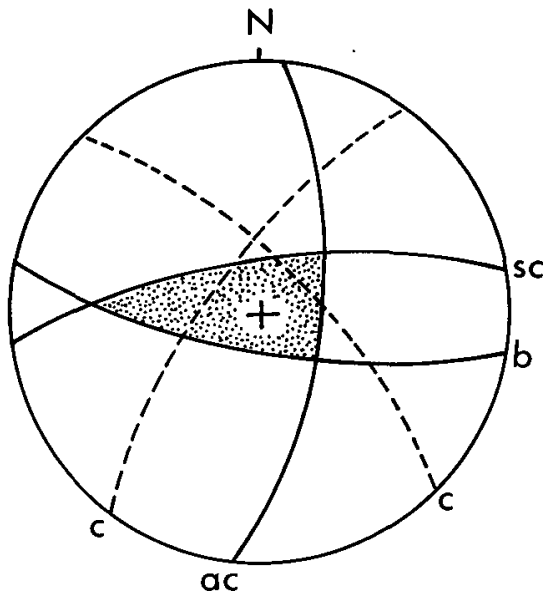

Fig. 7. Lower hemisphere, equal area projection of discontinuities at Goldenville. Great circles indicate average orientations of bedding (b), spaced cleavage (sc), joints oriented perpendicular to the major anticlinal axis (ac) and conjugate joints (c). Cleavage in the phyllite is parallel to bedding. Rare subhorizontal joints are not shown. The shaded triangle represents the dominant block geometry. Data taken from Hill, 1993.

tering and re-entering of the Stuart workings in 1988 revealed the presence of large amounts of surface debris which had dropped into workings on the $49 \mathrm{~m}$ (160 foot) level (Coates and Freckelton, 1989).

The mechanical behaviour of the near-surface rock mass in the vicinity of the fenced area has been monitored since 1991 using time domain reflectometry (TDR). It is not the purpose of this paper to describe time domain reflectometry, and the reader is referred to Hill (1993) for additional information on the principles and procedures of this method for monitoring rock mass movements. However, the results of the monitoring program are relevant to the potential for surface subsidence in the area. Time domain reflectometry is a technique for determining rock mass movements using coaxial cables in boreholes anchored directly to the rock mass with expansive grout (Dowding et al., 1989). TDR cables were installed in 8 boreholes (holes $1,2,5,6,9,11$, 12 and 15) drilled at north and south-trending plunges of 35 to $50^{\circ}$ (Figs. 3, 4) to intersect the crown pillars, hangingwalls and footwalls of several stopes in the vicinity of the fenced area. Movements in the rock mass generate defects in the cables, which in turn generate voltage reflections that are recorded by the TDR cable tester. An example of TDR output is given in Figure 8. Depths to planes of movement are determined by the time lag between signal generation and reflection, and are measured in metres. Shear movements are indicated by voltage spikes, with magnitude being related to spike amplitude (measured in mrho). Extension parallel to the borehole can be determined by the increase in distance over time between reference crimps emplaced on the cable prior to installation.

The TDR monitoring results indicate that both shear and extension movements occurred at numerous locations in all drill holes throughout the life of the project. Using drill hole \#9 as an example (Fig. 8), 14 separate spikes re- lated to shear movements can be recognized in metawacke below the borehole casing. Quantitative analysis of TDR shear movements is not possible yet, although work is ongoing to resolve this problem. However, laboratory tests on the coaxial cable used in this project (Hill et al., 1995) suggest that the aggregate amplitude of $\mathbf{4 7 0}$ mrho for the 14 TDR spikes in Figure 8 correspond to total shear movements on the order of $7 \mathrm{~cm}$ between June, 1991 and January, 1993. Simultaneously, the TDR cable underwent about $30 \mathrm{~cm}$ of extension, determined by measuring the change in distance between crimps A and B over the same time period (Fig. 8). Similar results were obtained in the other seven TDR monitoring holes. In drill hole \#1, for example, the amount of shear movement appears to be on the order of $9 \mathrm{~cm}$ along 12 separate discontinuities and the total extension is about 90 $\mathrm{cm}$ over the $5 \mathrm{~m}$ length of hole below the casing between June, 1991 and February, 1993. These are minimum values since the TDR cable failed by shear and/or extension at a depth of $17 \mathrm{~m}$ after six months. The spacing of the movement locations was 30 to $60 \mathrm{~cm}$ on average along the lengths of the drill holes, corresponding to a vertical spacing of about 20 to $40 \mathrm{~cm}$. Moreover, deformation was not uniform over time. Rather, the data indicate that at each plane of movement, there were long periods with little movement (measured in days or weeks), punctuated by relatively sudden movements. Movement was pervasive, occurring in all lithologies. However, there is a crude correlation between deformation and rock quality, with the greatest movements occurring in lithologies with RQD values less than $50 \%$ (Hill, 1993).

\section{Discussion and conclusions}

The subsidence features inside the fence (subsidence basins A, B, D and E) coincide with the abandoned open stopes exposed during the 1984 bulk sampling program by Goldenville Explorations Limited, and are clearly related to the settling of loose surface material used to plug those openings. The circular, steep-sided, $1.9 \mathrm{~m}$ deep pit south of drill hole \#6 (subsidence basin F) appears to mark the site of an old shaft on the Striker lead that has recently collapsed. However, the origin of the remaining small subsidence basins outside the fence and coinciding with the Hirschfeld and Chapel leads is more enigmatic.

The Goldenville mining district contains numerous nearsurface stopes with horizontal and vertical dimensions measuring in the tens to hundreds of metres. Many of these stopes remain open today, either because they were never backfilled or because of settlement of fill over time. Surface crown pillars, where preserved, are on the order of 1 to $2 \mathrm{~m}$ wide and as little as $2 \mathrm{~m}$ thick. The surface crown pillars are composed mainly of quartz and phyllite and have relatively low rock mass quality. The rock mass is divided into blocks defined mainly by cleavage and bedding planes, with joints providing additional release surfaces (Fig. 9). Individual blocks are most likely wedge to slab-like in shape and elongate parallel to the stopes. The 20 to $40 \mathrm{~cm}$ vertical spacing of the TDR-indicated shear movements correlates closely with 


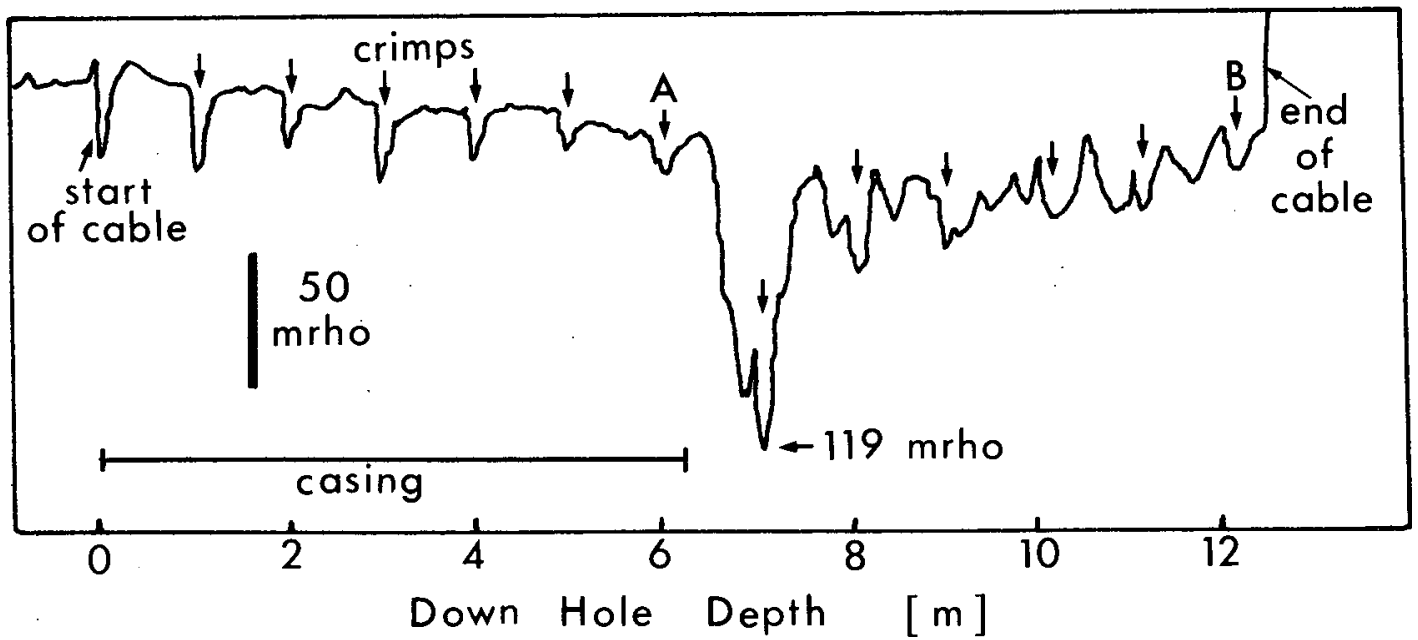

Fig. 8. TDR waveform for drillhole \#9 recorded on January 24,1993 . Short arrows indicate crimps emplaced prior to cable installation on June 20, 1991. Casing extends $6.2 \mathrm{~m}$ from surface. The aggregate spike amplitude between crimp A and crimp B is $470 \mathrm{mrho}$, after subtracting crimp reflections. At the time of installation, the right side of the waveform was similar to the left side, with only spikes related to crimps present.

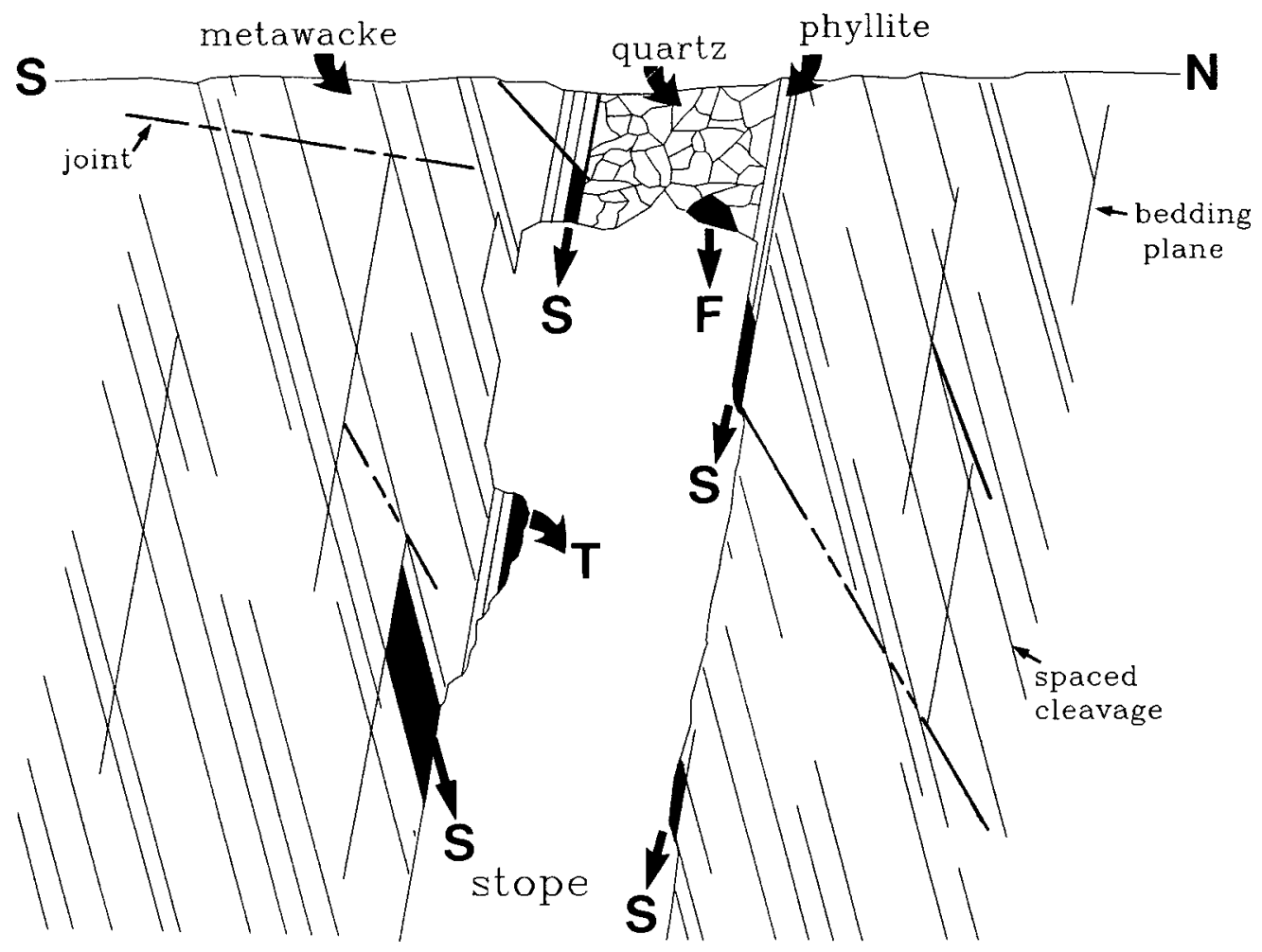

Fig. 9. Interpretive cross-section of a typical, near-surface, 1 to $2 \mathrm{~m}$ wide stope in the study area. Gradual enlargement of the stope is likely to take place by sliding (S) and toppling (T) failure of rock mass blocks in the side walls and sliding and falling (F) failure in the surface crown pillar.

the inferred block size of a few centimeters to 1 to $2 \mathrm{~m}$ in length. Time domain reflectometry data coupled with historical records indicate that the near-surface rock mass in and around abandoned stopes is undergoing progressive timedependent degradation involving translation and separation of blocks along numerous discontinuities. The observation that rock mass deformation is characterized by long periods with little movement punctuated by short periods of large movement supports this model. Gradual enlargement of the near-surface openings by gravity-induced sidewall spalling and upward caving of the roof, if it continues, must inevitably lead to eventual failure of the crown pillars and the development of additional surface subsidence basins.

Surface subsidence features currently exist in numerous Meguma mining districts such as Lake Catcha, Montague, Forest Hill, Wine Harbour, Country Harbour and Waverley (e.g., Goudge, 1957; see Fig. 1 for locations). The orientations and trench-like shapes of some of those features imply 
that they are related to abandoned stopes. It is not known if any of the existing surface subsidence features at Goldenville are related specifically to crown pillar failure. However, the data suggest that the near-surface rock mass at Goldenville is undergoing progressive degradation and that eventual crown pillar failure is likely to occur. Unfortunately, it is impossible to predict where or when such subsidence might occur due to the large number of variables and unknowns (e.g., stope locations, crown pillar dimensions, rock mass characteristics, water table fluctuations). Subsidence basins have been known to develop over underground mine openings as much as hundreds of years after mine closure (Dunrud, 1984; Whittaker and Reddish, 1989).

Aston, T.R.C., Betournay, M.C., Hill, J.D., and Charette, F. 1994. Application of TDR for monitoring the long term behaviour of Canadian abandoned metal mines. In Symposium and workshop on time domain reflectometry in environmental, infrastructure and mining applications. United States Bureau of Mines, Special Publication SP 19-94, pp. 518-527.

Bieniawski, Z.T. 1976. Rock mass classification in rock engineering. In Proceedings of the symposium on exploration for rock engineering. Johannesburg, 1, pp. 97-106.

Brunton, S. 1927. Goldenville gold district. Nova Scotia Department of Natural Resources, Annual Report 1927, Part 2, pp. $425-474$.

Contes, H.J. and Freckelton, D.J. 1989. Assessment report on the 1988 underground exploration program, development license 0103, Goldenville property, Guysborough County, Nova Scotia for Novagold Resources Inc. Nova Scotia Department of Natural Resources, Assessment Report, 28 p.

DeERE, D.U. 1964. Technical description of rock cores for engineering purposes. Rock Mechanics and Engineering Geology, 1, pp. 17-22.

Dowding, C.H., Su, M.B., and O'Connor, K. 1989. Measurement of rock mass deformation with grouted coaxial antenna cables. Rock Mechanics and Rock Engineering, 22, pp. 123.

DunRud, C.R. 1984. Coal mine subsidence - western United States. In Man-induced land subsidence. Edited by T.L. Holzer. Reviews in Engineering Geology, Number VI, pp. 151-194.

Evans, G.R. 1938. Gold mining in Nova Scotia during the nineteenth century. M.A. thesis, Dalhousie University, Nova Scotia, 162 p.

FARIBAult, E.R. 1898. Goldenville gold district, Guysborough County, Nova Scotia. Geological Survey of Canada, Map 645.

---- 1899. On the gold measures of Nova Scotia and deep mining. Journal of the Canadian Mining Institute, pp. 119-151.

Forrester, D.J., Courtney, R.C., Forgeron, S.V., Stewart, J., and Hart, S.T. 1995. Seafloor mining subsidence in the Sydney Coalfield. C.I.M. Annual General Meeting, 11 p.
Gillis, K.S. 1992. Report on mine subsidence in the Pictou Coalfield. Nova Scotia Department of Natural Resources, Open File Report 92-018, 18 p.

GoudGE, M.G. 1957. Unpublished memorandum to the Chief Mining Engineer. Nova Scotia Department of Natural Resources.

Hedley, P.M. 1941. Geology and structure as related to mining. Transactions of the Canadian Institute of Mining and Metallurgy, 44, pp. 251-258.

HILL, J.D. 1993. Monitoring of surface crown pillar deformation at Goldenville, Nova Scotia using time domain reflectometry. Final report, Contract No. 23440-0-9245/01-SZ, Canada Centre for Mineral and Energy Technology, Ottawa, 87 p.

Hill, J.D., Gillis, S., and SMART, I. 1995. Laboratory evaluation of time domain reflectometry cable displacement and signal response. Final report, Contract No. 23440-4-1249/01SQ, Canada Centre for Mineral and Energy Technology, Ottawa, $64 \mathrm{p}$.

KuUsisto, K.M. 1988. Gold mining and milling in the Sherbrooke gold district 1861-1906. Nova Scotia Department of Education, Curatorial Report Number 58, 120 p.

Malcolm, W. 1929. Gold fields of Nova Scotia. Geological Survey of Canada, Memoir 156, 253 p.

Messervey, J.P. 1936. Unpublished letter to Inspector of Mines. Nova Scotia Department of Natural Resources.

..-. 1937. Unpublished letter to Deputy Minister of Mines. Nova Scotia Department of Natural Resources.

-..-- 1940. Unpublished letter to Deputy Minister of Mines. Nova Scotia Department of Natural Resources.

Province of Nova Scotia. 1911. Annual report of the Department of Mines 1910. Nova Scotia Department of Natural Resources, pp. 133-134.

---- 1939. Annual report of the Department of Mines 1938. Nova Scotia Department of Natural Resources, pp. 94-96.

Schenk, P.E. 1978. Synthesis of the Canadian Appalachians. Geological Survey of Canada, Paper 78-13, pp. 111-136.

Stephens, D.E. 1974. It happened at Moose River. Lancelot Press Limited, 99 p.

Stewart, G.W. 1903. Methods of gold mining in Nova Scotia. The Nova Scotian, October, pp. 31-33.

WALDRON, J.W.F. 1987. Sedimentology of the Goldenville-Halifax transition in the Tancook Island area, South Shore, Nova Scotia. Geological Survey of Canada, Open File Report 1536, $26 \mathrm{p}$.

WhitTaKer, B.N. and RedDish, D.J. 1989. Subsidence Occurrence, Prediction and Control. Developments in Geotechnical Engineering, Number 56, Elsevier, New York, 528 p.

Williams, H. and Hatcher, R.D. 1982. Suspect terranes and accretionary history of the Appalachian Orogen. Geology, 10, pp. 530-536. 